\title{
HUBUNGAN PENGETAHUAN COVID-19 DENGAN PERILAKU PENCEGAHAN PENULARAN DI MASA PANDEMI PADA SISWA SMPN 1 SEKAMPUNG UDIK LAMPUNG TIMUR
}

\author{
Umi Romayati ${ }^{1}$, Wahid Tri Wahyudi ${ }^{*}$, Ade Gunawati Sandi ${ }^{3}$
}

1Dosen Program Studi Ilmu Keperawatan Universitas Malahayati

Email : romayatiumi@yahoo.com

${ }^{2}$ Dosen Program Studi Ilmu Keperawatan Universitas Malahayati

Email : nisun.yudi@yahoo.com

$3^{*}$ Mahasiswa Program Studi Keperawatan Universitas Malahayati.

Email: adegunawatisandi@gmail.com

\section{ABSTRACT: THE RELATIONSHIP OF COVID-19 KNOWLEDGE WITH TRANSMISSION PREVENTION BEHAVIOR IN PANDEMIC TIMES IN STUDENTS OF SMPN 1 SEKAMPUNG UDIK EAST LAMPUNG IN 2021.}

Introduction: Coronavirus Disease 2019 (COVID-19) is a new form of Coronavirus that causes an infectious disease. The number of persons infected with this virus is continuing to rise, and it can affect everyone from children to the elderly. Because there is currently no known remedy for this sickness, the government can only promote it by imposing a large-scale social restriction (PSBB) policing scheme. The impact of public awareness of Covid-19 and knowledge of health protocols on the PSBB's successful implementation cannot be separated. According to the results of a pre-survey done at SMPN 1 Sekampung Udik, East Lampung, which included an interview with one of the teachers, there were five teachers who tested positive for COVID-19 and There were still a lot of students who didn't follow the school's health regulations.

Objective: To find out the relationship between knowledge of Covid-19 and transmission prevention behavior in students at SMPN 1 Sekampung Udik, East Lampung.

Methods: This type of quantitative research was carried out at SMPN 1 Sekampung Udik, East Lampung, using an analytical observational research design using a cross sectional method. The participants in this study were all 651 students from SMPN 1 Sekampung Udik in East Lampung. With stratified random sampling and then accidental sampling, a minimum sample of 249 respondents was produced. Data was gathered through the use of a Google Forms questionnaire that was distributed to responders. The data was analyzed in two ways: univariate (frequency distribution) and bivariate (chi square).

Results: Based on the results of statistical tests, it is known that 135 (54.2\%) respondents with poor knowledge and 130 (52.2\%) negative behavior. The $p$ value is 0.022 , with an Odd Ratio of 1.862 .

Conclusion: There is a relationship between knowledge of covid-19 and behavior to prevent transmission during the pandemic for students of SMPN 1 Sekampung Udik, East Lampung in 2021. It is recommended for schools to further increase counseling about preventing transmission of covid-19 to students so as to minimize the incidence of covid-19.

Keywords: knowledge, behavior, Covid-19 


\section{INTISARI: HUBUNGAN PENGETAHUAN COVID-19 DENGAN PERILAKU PENCEGAHAN PENULARAN DI MASA PANDEMI PADA SISWA SMPN 1 SEKAMPUNG UDIK LAMPUNG TIMUR TAHUN 2021}

Pendahuluan: Coronavirus Disease 2019 (COVID-19) ialah penyakit menular yang disebabkan oleh virus jenis baru. Peningkatan kasus oleh virus ini terus meningkat, berbagai masyarakat dari anak-anak sampai dengan lansia pun dapat terjangkit virus ini. Sampai dengan saat ini belum diketahui obat dari penyakit ini sehingga pemerintah hanya dapat melakukan upaya promotif dengan memberlakukan kebijakan pembatasan sosial berskala besar (PSBB). Berjalannya PSBB dengan baik tidak lepas dari pengaruh pengetahuan masyarakat tentang Covid-19 dan pengetahuan tentang protokol kesehatan. Berdasarkan hasil pra survey yang dilakukan di SMPN 1 Sekampung Udik Lampung Timur dengan mewawancarai salah satu guru didapatkan ada 5 guru yang sudah dinyatakan positif terjangkit COVID-19 dan masih banyak para siswa yang tidak mematuhi protokol kesehatan di sekolah.

Tujuan: Diketahui hubungan antara pengetahuan Covid-19 dengan perilaku pencegahan penularan pada siswa di SMPN 1 Sekampung Udik Lampung Timur.

Metode: Jenis penelitian kuantitatif, rancangan penelitian ini analytical observational dengan pendekatan cross sectional, telah dilakukan di SMPN 1 Sekampung Udik Lampung Timur. Populasi dalam penelitian ini adalah seluruh siswa SMPN 1 Sekampung Udik Lampung Timur yang berjumlah 651 siswa. Sampel minimum yang didapatkan berjumlah 249 responden dengan teknik stratified random sampling lalu accidental sampling. Pengambilan data menggunakan kuisioner google form yang dibagikan kepada responden. Analisa data secara univariat (distribusi frekuensi) dan bivariat (chi square).

Hasil: Berdasarkan hasil uji statistik, diketahui 135 (54,2\%) responden dengan pengetahuan tidak baik dan $130(52,2 \%)$ perilaku negatif. Didapatkan p-value 0,022, dengan Odd Ratio 1,862.

Kesimpulan: Ada hubungan antara pengetahuan covid-19 dengan perilaku pencegahan penularan di masa pandemi pada siswa SMPN 1 Sekampung Udik Lampung Timur Tahun 2021. Bagi pihak sekolah disarankan untuk lebih meningkatkan penyuluhan tentang pencegahan penularan covid-19 terhadap siswa sehingga dapat meminimalisir angka kejadian covid-19.

Kata Kunci : pengetahuan, perilaku, Covid-19 


\section{PENDAHULUAN}

Penyakit Coronavinus 2019( COVID19) ialah penyakit menular yang diakibatkan oleh tipe baru coronavirus. Penyakit ini diawali pada akhir tahun pada saat permasalahan pneumonia yang tidak dikenal penyebabnya timbul di Wuhan, Cina Desember 2019 (Li et al, 2020).

Bersumber pada hasil penyelidikan epidemiologi, permasalahan tersebut diprediksi berhubungan dengan Pasar Seafood di Wuhan. Bertepatan pada 7 Januari 2020, Pemerintah Cina setelah itu mengumumkan kalau pemicu permasalahan tersebut merupakan Coronavirus tipe baru yang setelah itu diberi nama SARS- CoV-2 (Severe Acute Respiratory Syndrome Coronavirus 2). Virus ini berasal dari famili yang sama dengan virus pemicu SARS serta MERS. Walaupun berasal dari famili yang sama, tetapi SARS-CoV-2 lebih meluas dibanding dengan SARS-CoV serta MERS-CoV (CDC China, 2020; Aziza, L., Akmarina, A., Ihsan, M. (Ed.). 2020).

Coronavirus ialah zoonis (ditularkan antara hewan serta manusia). Penelitian membuktikan jika SARS ditransmisikan dari hewan luwak (civet cats) ke manusia serta MERS dari unta ke manusia. Ada pula, hewan yang jadi sumber penularan COVID-19 ini masih belum dikenal. Masa inkubasi COVID-19 kurang lebih 5-6 hari, dengan range antara 1 serta 14 hari tetapi bisa mencapai 14 hari. Resiko penularan paling tinggi didapatkan di hari-hari awal penyakit diakibatkan oleh konsentrasi virus pada sekret yang besar. Orang yang terinfeksi bisa langsung menularkan hingga dengan 48 jam saat sebelum onset indikasi (presimptomatik) serta hingga dengan 14 hari sehabis onset indikasi.

Sebuah studi Du Z et. al, (2020) mengatakan bahwa 12,6\% menunjukkan penularan presimptomatik. Penting untuk mengenali periode presimptomatik sebab membolehkan virus menyebar lewat droplet ataupun kontak dengan barang yang terkontaminasi. Selaku catatan, kalau ada permasalahan konfirmasi yang tidak bergejala (asimptomatik), walaupun resiko penularan sangat rendah namun masih terdapat kemungkinan kecil untuk berlangsungnya penularan.

Data kasus COVID-19 di Indonesia diketahui sampai dengan tanggal 25 Maret 2021 mencapai 1.471.225 dari 273.523.615 jumlah penduduk di Indonesia dengan angka kematian mencapai 39.865, angka ini terus meningkat hingga saat ini (World Health Organization, 2021). Wiku Adisasmito sebagai juru bicara penangan Covid-19 di Indonesia mengatakan bahwa $8,87 \%$ atau sebesar 59.776 kasus dari total kasus Corona di Indonesia ialah anak usia sekolah. Beliau menjelaskan, rentang usia sekolah terdapat 5 kelompok, yakni usia 0-2 tahun (Paud), 3-6 tahun (TK), 7-12 tahun (SD), 13-15 tahun (SMP), dan 16-18 tahun (SMA) (Dwianto, 2021). Hal ini mengkhawatirkan dan akan berdampak buruk pada demografi dan generasi Indonesia unggul di masa yang akan datang. Masa remaja adalah masa yang diartikan sebagai masa perkembangan transisi antara masa kanak-kanak dan dewasa yang meliputi perubahan biologis, kognitif, dan sosio-emosional (Santrock, 2003; Ahyani \& Astuti, 2018). Reaksi stereotip anak muda merupakan anak yang tidak apik, tidak bisa dipercaya serta cenderung rusak dan berperilaku destruktif mengakibatkan orang dewasa harus membimbing serta mengawasi kehidupan remaja muda yang khawatir akan tanggung jawab serta tidak simpatik terhadap sikap remaja normal. Stereotip pula mempengaruhi konsep serta perilaku diri sendiri (Santrock, 2003; Ahyani \& Astuti, 2018).

Dari hasil data yang didapat angka kejadian COVID-19 di kabupaten Lampung timur terus meningkat walaupun pemerintah telah memberikan edukasi dan meminta masyarakat mematuhi protokol kesehatan. Satuan Tugas COVID19 Lampung Timur mengeluarkan edaran untuk masyarakat agar mematuhi aturan baru yang sudah dibuat guna mencegah penyebaran virus Corona. Berdasarkan hasil prasurvey di SMPN 1 Sekampung Udik Lampung Timur pada tanggal 3 April 2021 diketahui bahwa sekolah masih 
menunda kegiatan belajar mengajar (KBM), namun ada kebijakan sendiri yang disepakati oleh sekolah bahwa setiap hari ada beberapa siswa yang datang ke sekolah untuk melaksanakan piket di sekolah dengan didamping oleh guru kelas dan tetap sesuai dengan protokol kesehan yang telah ditetapkan pemerintah. Dalam sehari ada 2 sampai dengan 3 kelas yang melaksanakan piket, biasanya sekali piket dalam sehari kelas mengirimkan 10 orang siswanya. Wawancara juga dilakukan kepada salah satu guru disana, dari hasil wawancara dan observasi langsung diketahui bahwa masih banyak siswa yang tidak menerapkan protokol kesehatan saat pelaksanakan piket harian seperti tidak memakai masker dan masih berkerumun. Dari informasi yang didapat juga ada 5 guru dari SMPN 1 Sekampung Udik Lampung Timur terjangkit COVID-19.

Remaja merupakan bagian masyarakat yang tidak bisa dianggap remeh dalam upaya pencegahan penularan penyakit ini. Menerapkan protokol kesehatan untuk memutus rantai penyebaran Covid-19, terutama pada remaja, membutuhkan pemahaman dan pengetahuan yang baik.

\section{METODELOGI PENELITIAN}

Penelitian ini merupakan jenis penelitian kuantitatif dengan metode Analytical Observational. Sampelnya siswa SMPN 1 Sekampung Udik Lampung Timur Tahun 2021. Teknik sampling yang digunakan dalam Penelitian ini dengan Simple Random Sampling. Pengambilan sampel menggunakan rumus Slovin. Jumlah populasi 651 siswa dan didapatkan sampel 249 siswa. Instrumen dalam penelitian adalah google form yang berisi pertanyaan tentang pengetahuan covid19 dan pertanyaan tentang perilaku di masa pendemi.

Kuisioner tentang pengetahuan Covid19 yang digunakan adalah kuisioner baku yang telah dimodifikasi oleh peneliti, yang telah di uji validitas nya yang diambil dari jurnal keperawatan STIK Husada Jombang tentang Validitas dan Reliabilitas Kuesioner Pengetahuan Tentang Covid-19 (SARS-Cov-2). Uji reliabilitas kuesioner pada penelitian ini menggunakan uji Cronbach Alpha Coefficient dengan hasil nilai $r=0.971$.

Kuesioner pengetahuan terdiri dari 10 pertanyaan dengan pilihan jawaban benar dan salah. Benar diberi skor 1 dan salah diberi skor 0 . Hasil ukur pengetahuan dikategorikan menjadi tingkat pengetahuan kategori baik nilainya > 50\% dan tingkat pengetahuan kategori kurang baik nilainya $\leq 50 \%$ (Budiman \& Riyanto, 2013). Sedangkan untuk kuisioner perilaku terdiri dari 7 pertanyaan dengan pilihan jawaban menggunakan skala likert. Skor yang diberikan untuk kuesioner perilaku pemyataan positif adalah: Skor Sangat Setuju 4, Skor Setuju 3, Skor Tidak Setuju 2, Skor Sangat Tidak Setuju 1. Hasil ukur perilaku dapat di iterpretasikan menjadi: Perilaku Positif jika skor $\mathrm{T} \geq$ mean dan Perilaku Negatif jika skor $\mathrm{T}<$ mean (Azwar, 2011; Lutviyah, 2017).

Setelah mendapat persetujuan dari responden dengan menceklis informed consent pada bagian awal google form, responden diarahkan secara otomatis ke bagian pertanyaan. Pengolahan data menggunakan aplikasi Ms.Exel dan SPSS versi 25.

Penelitian ini sudah lulus kelaikan etik dari Komite Etik Riset Kesehatan Fakultas Kedokteran Universitas Malahayati Bandar Lampung di Indonesia dengan Nomor: 1747 EC/KEP-UNMAL/V/2021. 
HASIL PENELITIAN DAN PEMBAHASAN

ANALISA UNIVARIAT

Distribusi frekuensi karakteristik responden

\begin{tabular}{|c|c|c|c|}
\hline Karakteristik & $\mathbf{N}$ & $\%$ & $\mathrm{M} \pm \mathrm{SD}$ \\
\hline \multicolumn{4}{|l|}{ Jenis Kelamin } \\
\hline - Laki-laki & 88 & 35,3 & \\
\hline - Perempuan & 161 & 64,7 & \\
\hline \multicolumn{4}{|l|}{ Umur (Tahun) (rentang) } \\
\hline$-12-15$ & 249 & 100 & $13,95 \pm 0,874$ \\
\hline \multicolumn{4}{|l|}{ Kelas } \\
\hline-7 & 85 & 34,1 & \\
\hline 8 & 85 & 34,1 & \\
\hline-9 & 79 & 31,7 & \\
\hline \multicolumn{4}{|l|}{ Suku } \\
\hline - Lampung & 96 & 38,6 & \\
\hline Jawa & 116 & 46,6 & \\
\hline Bali & 21 & 8,4 & \\
\hline Palembang & 7 & 2,8 & \\
\hline - Lain-lain & 9 & 3,6 & \\
\hline \multicolumn{4}{|l|}{ Agama } \\
\hline - Islam & 201 & 80,7 & \\
\hline - Kristen & 18 & 7,2 & \\
\hline - $\quad$ Hindu & 23 & 9,2 & \\
\hline - Budha & 1 & 0,4 & \\
\hline - Lain-lain & 6 & 2,4 & \\
\hline
\end{tabular}

Usia rata-rata dari 249 responden yang berpartisipasi dalam penelitian ini adalah 13,94 tahun, dengan rentang usia antara 12 dan 15 tahun. Mayoritas peserta adalah perempuan (64,7\%). Peserta dari kelas 7 berjumlah 85 siswa $(34,1 \%)$, kelas 8 berjumlah 85 siswa $(34,1 \%)$ dan kelas 9 berjumlah 79 siswa $(31,7 \%)$. Rata-rata responden bersuku jawa sebanyak 116 (46,6\%), beragama islam sebanyak 201 $(80,7 \%)$.

\section{Distribusi Frekuensi Pengetahuan Responden}

\begin{tabular}{ccc}
\hline $\begin{array}{c}\text { Pengetahuan Tentang } \\
\text { Covid-19 }\end{array}$ & $\begin{array}{c}\text { Frekuensi } \\
(\mathbf{N}=\mathbf{2 4 8 )}\end{array}$ & Persentase (\%) \\
\hline Kurang Baik & 135 & 54,2 \\
\hline Baik & 114 & 45,8 \\
\hline Total & 249 & $100 \%$ \\
\hline
\end{tabular}

Dari tabel di atas diketahui sebanyak 135 (54,2\%) pengetahuan reponden tentang covid-19 kurang baik dan sebanyak $114 \quad(45,8 \%)$ responden berpengetahuan baik.
Ini membuktikan bahwa responden dengan pengetahuan kurang baik lebih banyak dari responden dengan perilaku baik. 
Analisa bivariat

Hubungan Pengetahuan Covid-19 Dengan Perilaku Pencegahan Penularan Covid-19 di SMP Negeri 1 Sekampung Udik Lampung Timur

\begin{tabular}{|c|c|c|c|c|c|c|c|c|}
\hline \multirow{3}{*}{$\begin{array}{c}\text { Pengetahuan } \\
\text { Tentang } \\
\text { Covid-19 }\end{array}$} & \multicolumn{4}{|c|}{$\begin{array}{c}\text { Perilaku Pencegahan } \\
\text { Penularan Covid-19 }\end{array}$} & \multirow{2}{*}{\multicolumn{2}{|c|}{ Total }} & \multirow{3}{*}{$\begin{array}{c}P \\
\text { Value }\end{array}$} & \multirow{3}{*}{$\mathrm{OR}(95 \% \mathrm{Cl})$} \\
\hline & \multicolumn{2}{|c|}{ Negatif } & \multicolumn{2}{|c|}{ Positif } & & & & \\
\hline & $\mathrm{N}$ & $\%$ & $\mathrm{~N}$ & $\%$ & $\mathrm{~N}$ & $\%$ & & \\
\hline Kurang Baik & 80 & 59,3 & 55 & 40,7 & 135 & 100 & & 1,862 \\
\hline Baik & 50 & 43,9 & 64 & 56,1 & 114 & 100 & 0,022 & $(1,124-$ \\
\hline Total & 130 & 52,2 & 119 & 47,8 & 249 & 100 & & $3,084)$ \\
\hline
\end{tabular}

Berdasarkan tabel di atas diketahui bahwa dari 135 responden dengan pengetahuan kurang baik terdapat sebanyak 80 $(59,3 \%)$ berperilaku negatif dan sebanyak $55(40,7 \%)$ berperilaku positif. Dari sebanyak 114 responden dengan pengetahuan baik terdapat sebanyak $50(43,9 \%)$ berperilaku negatif dan $64(56,1 \%)$ berperilaku positif. Nilai $p$ value pada analisa bivariat di atas

\section{PEMBAHASAN}

Dalam penelitian ini responden berjumlah 249 siswa yang sebagian besar adalah perempuan, usia rata-rata 13,95 tahun. Rata-rata responden beragama islam dan ber suku Jawa. Responden terdiri dari tiga kelas yaitu kelas 7,8 dan kelas 9, dimana pengambilan sampel telah dilakukan sesuai dengan perhitungan yang direncanakan sebelumnya.

Hasil analisis yang dilakukan peneliti didapatkan sebanyak 114 $(45,8 \%)$ responden berpengetahuan baik tentang covid-19, dan sebanyak $135 \quad(54,2 \%) \quad$ responden berpengetahuan kurang baik.

Dari hasil yang didapat diketahui sebanyak $220 \quad(88,4 \%)$ responden menjawab pertanyaan paling banyak benar pada pertanyaan: Penularan virus Covid19 dapat terjadi melalui kontak didapatkan 0,022 dimana nilai $p<$ 0,05 yang artinya ada hubungan yang bermakna antara pengetahuan covid-19 dengan perilaku pencegahan penularan covid-19 dimasa pandemi pada siswa SMPN 1 Sekampung Udik Lampung Timur tahun 2021. Nilai OR 1,862 yang artinya responden dengan pengetahuan baik memiliki peluang 1,862 kali berperilaku positif.

langsung dengan orang yang terinfeksi dan kontak tidak langsung dengan permukaan atau benda yang digunakan pada orang yang terinfeksi. Sedangkan untuk jawaban salah sebanyak $170(68,3 \%)$ paling banyak terletak pada pertanyaan: Jarak aman yang dianjurkan dalam praktik Physical Distancing (menjaga jarak dengan orang lain) adalah 1 meter.

Menurut Notoatmodjo (2010), faktor yang mempengaruhi pengetahuan antara lain yaitu: faktor pendidikan, pekerjaan, pengalaman, keyakinan, social budaya (Wawan \& Dewi, 2018).

Hal ini sejalan dengan survey yang dilakukan oleh UNICEF terhadap 4000 remaja terkait Covid19 yang menunjukkan masih ada remaja (25\%) yang tidak tahu sama sekali tentang Covid-19. Ada yang tahu gejala penyakit ini, namun belum tahu cara pencegahan. 
Terjadi peningkatan pengetahuan setelah difasilitasi dengan informasi kepada remaja. Namun sebagian besar masih belum melakukan physical distancing (Habibie, 2020; Anggreni D \& Safitri C, 2020).

Hasil penelitian ini juga sejalan dengan hasil penelitian yang dilakukan oleh Mudawaroch, R.E (2020) tentang Pengaruh Pengetahuan dan Sikap Terhadap Perilaku Mahasiswa dalam Mengahadapi Virus Corona pada 90 responden, didapatkan bahwa pengetahuan mahasiswa baik tentang COVID-19 sebanyak 32 orang dan pengetahuan tidak baik sebanyak 58 orang.

Berdasarkan teori dan pendapat peneliti bahwa faktor yang mempengaruhi kurangnya pengetahuan responden adalah faktor pendidikan dan pengalaman. Pendidikan responden yang masih SMP dan pengalaman yang belum cukup di umur kisaran 12-15 tahun.

Diketahui, sebanyak 130 $(52,2 \%)$ responden dengan perilaku negatif sedangkan sebanyak 119 $(47,8 \%)$ responden dengan perilaku positif. Diketahui dari jawaban responden sebanyak $148 \quad(59,4 \%)$ tentang perilaku pencegahan penularan covid-19 dimasa pandemi didapatkan jawaban kategori selalu, paling banyak terletak pada pertanyaan: Saya menggunakan masker pada saat berpergian. Sedangkan sebanyak $15 \quad(6,0 \%)$ responden untuk jawaban kategori tidak pernah paling banyak terletak pada pertanyaan: Saya tidak berjabat tangan dengan orang lain untuk situasi saat ini.

Notoatmodjo (2014) menjelaskan dalam pembentukan dan atau perubahan, perilaku dipengaruhi oleh beberapa faktor yang berasal dari dalam dan luar individu itu sendiri seperti: pengetahuan, persepsi, emosi, motivasi, lingkungan sekitar, baik fisik atau non fisik seperti, iklim, manusia, sosial ekonomi, kebudayaan, dan sebagainya (Damayanti, 2017).

Hasil penelitian ini sejalan dengan hasil penelitian yang dilakukan oleh Mudawaroch, R.E (2020) tentang Pengaruh Pengetahuan dan Sikap Terhadap Perilaku Mahasiswa dalam Mengahadapi Virus Corona pada 90 responden didapatkan responden dengan perilaku baik sebanyak 40 orang serta perilaku tidak baik sebanyak 50 orang, ini membuktikan bahwa perilaku mahasiswa dalam penelitian tersebut lebih banyak yang tidak baik daripada perilaku baik.

Dari hasil jawaban responden, peneliti berpendapat mengapa responden yang berperilaku negatif lebih banyak dari responden berperilaku positif, menurut peneliti hal ini disebabkan oleh faktor pengetahuan yang masih kurang, terlihat dari jawaban responden dalam kuisioner pengetahuan yang masih banyak pengetahuan kurang baik daripada pengetahuan baik.

Hasil analisa bivariat yang didapatkan bahwa sebanyak 114 responden dengan pengetahuan baik, $64(56,1 \%)$ berperilaku positif dan sebanyak $50 \quad(43,9 \%)$ berperilaku negatif. Sebanyak 135 responden dengan pengetahuan kurang baik, $55(40,7 \%)$ berperilaku positif dan $80 \quad(59,3 \%)$ responden berperilaku negatif. Nilai $p$ value pada analisa bivariat di atas didapatkan 0,022 yang berarti nilai $p<a 0,05$ yang menunjukan bahwa ada hubungan yang signifikan antara pengetahuan tentang covid19 dengan perilaku pencegahan penularan covid-19 di masa pandemi pada siswa SMPN 1 Sekampung Udik Lampung Timur Tahun 2021. Nilai OR sebesar 1,862 yang menunjukan bahwa responden dengan pengetahuan baik 
berpeluang 1,862 kali memiliki perilaku positif.

Hasil penelitian ini sejalan dengan teori Notoatmodjo (2014) yang menjelaskan dalam pembentukan dan atau perubahan, perilaku dipengaruhi oleh beberapa faktor yang berasal dari dalam dan luar individu itu sendiri seperti: pengetahuan, persepsi, emosi, motivasi, lingkungan sekitar, baik fisik atau non fisik seperti, iklim, manusia, sosial ekonomi, kebudayaan, dan sebagainya (Damayanti, 2017).

Hal ini juga sejalan dengan Teori Lawrence green (1980) yang mengatakan perilaku manusia dipengaruhi dari pengetahuan, sikap, kepercayaan, keyakinan, nilai-nilai dan sebagainya (Damayanti, 2017).

Hasil penelitian ini sejalan dengan penelitian yang dilakukan oleh Mudawaroch, R.E (2020) tentang Pengaruh Pengetahuan dan Sikap Terhadap Perilaku Mahasiswa dalam Mengahadapi Virus Corona, dimana pengetahuan berbanding lurus dengan perilaku mahasiswa dalam menghadapi virus corona.

Dalam penelitian ini peneliti menarik kesimpulan bahwa faktor pengetahuan yang kurang dipengariuhi oleh faktor demografi seperti pendidikan responden yang masih SMP, umur responden yang masih remaja dan pengalaman responden yang belum terlalu banyak. Sedangkan untuk perilaku pencegahan penularan responden yang negatif dipengaruhi oleh faktor pengetahuan yang kurang itu sendiri, keyakinan responden dimana mayoritas responden beragama islam yang mengedepankan sopan santun dan tatakrama yang terlihat dari jawaban responden di soal masihnya berjabat tangan dimasa pandemi dengan skor yang masih tinggi.
Selain itu juga responden yang berpengetahuan kurang baik tapi berperilaku positif dan responden dengan pengetahuan baik masih ada yang berperilaku negatif, menurut peneliti hal ini dipengaruhi oleh lingkungan sekitar, baik fisik atau non fisik seperti manusia dan kebudayaan dimana remaja seusia mereka masih terpengaruh dan ikuta-ikutan dengan apa yang dilakukan temannya. Mayoritas responden juga bersuku jawa dan lampung dimana suku tersebut masih sangat kental dengan kebudayaan mereka.

\section{KESIMPULAN}

Dari 249 responden, sebanyak 88 $(35,3 \%)$ responden berjenis kelamin laki-laki dan sebanyak 161 $(64,7 \%)$ responden berjenis kelamin perempuan. Mayoritas responden beragama islam sebanyak 201 (80,7\%) dan bersuku jawa sebanyak 116 (46,6\%).

Dari 249 responden didapatkan bahwa responden dengan pengetahuan baik tentang covid-19 sebanyak $114 \quad(45,8 \%)$, dan responden dengan pengetahuan kurang baik sebanyak 135 (54,2\%). Hasil ini menunjukan responden dengan pengetahuan kurang baik lebih banyak dari pada responden dengan pengetahuan baik tentang covid-19.

Hasil analisis perilaku pencegahan penularan covid-19 di masa pandemi didapati bahwa responden dengan perilaku negatif sebanyak $130 \quad(52,2 \%)$ sedangkan responden dengan perilaku positif sebanyak $119 \quad$ (47,8\%). Ini menunjukan bahwa responden lebih banyak yang berperilaku negatif dibandingkan dengan responden berperilaku positif.

Ada hubungan yang bermakna antara pengetahuan tentang covid19 dengan perilaku pencegahan 
penularan covid-19 di masa pandemi pada siswa SMPN 1 Sekampung Udik Lampung Timur $(p$ value 0,022 ).

\section{SARAN}

Peneliti selanjutnya diharapkan dapat melakukan penelitian tentang faktor pendukung dan faktor penguat yang mempengaruhi perilaku.

\section{DAFTAR PUSTAKA}

Ahyani, L.N. \& Astuti, D. (2018). Buku ajar psikologi anak dan remaja. Kudus: Badan Penerbit Universitas Muria Kudus. E-book

Anggreni, D. \& Safitri, C.A. (2020). Hubungan pengetahuan remaja tentang covid-19 dengan kepatuhan dalam menerapkan protokol kesehatan di masa new normal. Jurnal Hospital Majapahit Vol 12 No.2.

Aziza, L., Akmarina, A., Ihsan, M. (Ed.). (2020). Pedoman pencegahan dan pengendalian corona virus disease (Covid-19). Jakarta, Indonesia: Kementrian Kesehatan Republik Indonesia. E-book Diakses dari:

https: / / InfeksiEmerging.kem kes.go.id

Cahayaningrum, R. (2019). Tingkat pengetahuan remaja tentang kehamilan tidak diinginkan pada siswi kelas viii smp muhammadiyah bambanglipuro bantul. Yogyakarta. KTI. Politeknik Kesehatan Kementrian Kesehatan. Diakses dari: http://eprints.poltekkesjogj a.ac.id/2337/

Dinkes. (2021).

Dashboard pemantauan Covid-19 provinsi lampung. Lampung, Indonesia: Dinas Kesehatan
Provinsi Lampung. Diakses dari:

https: / / covid19.lampungpro v.go.id/

Heryana, A. (2019). Buku ajar metodologi penelitian kesehatan masyarakat. Jakarta: e-book tidak dipublikasikan.

Irwan. (2017). Etika dan perilaku kesehatan. Yogyakarta, Indonesia: CV. Absolute Media. E-book.

KPCPEN. (2021). Peta sebaran Covid-19. Jakarta, Indonesia: Komite Penanganan COVID-19 dan Pemulihan Ekonomi Nasional. Diakses dari: https: / / covid19.go.id/petasebaran-covid19

Li, Q. et al. (2020). Early transmission dynamics in wuhan china of novel coronavirus infected pneumonia. The New England Journal Of Medicine. doi.org/10.1056/NEJMoa200 1316

Lutviyah. (2017). Hubungan perilaku orang tua terhadap kemampuan toilet training pada anak usia toddler (1836 bulan). Jombang. Skripsi. Sekolah Tinggi Ilmu Kesehatan Insan Cendika Medika. Diakses dari: http://repo.stikesicmejbg.a c.id/215/1/SKRIPSI\%20LUTVI YAH\%20PERPUS.pdf

Masturoh, I. \& Anggita, N. (2018). Metodologi penelitian kesehatan. Jakarta: e-book KEMENKES RI

Moudy, J. \& Syakurah, R.A. (2020). Pengetahuan terkait usaha pencegahan coronavirus disease (Covid-19) di indonesia. Higeia Journal of Public Health Research And Development. doi : 10.15294 /higeia/v4i3/37844 
Pribadi, T. et al. (2020). Pedoman umum penulisan skripsi edisi ke 5. Bandar Lampung: LPPM Universitas Malahayati Bandar Lampung

Prihati, D.R., Wirawati, M., \& Supriyanti, E. (2020). Analisis pengetahuan dan perilaku masyarakat di kelurahan baru kotawaringin barat tentang covid 19. Jurnal Menuju: Malahayati Nursing Journal, P-Issn: 2655-2728 E-Issn: 2655-4712 Volume 2, Nomor 4 September 2020 Hal 780790.doi:

10.33024/manuju.v2i4.3073

Rinaldi, S.F \& Mujianto, B. (2017). Metodelogi Penelitian dan Statistik. Jakarta: e-book KEMENTRIAN KESEHATAN RI

Sanifah, L.J. (2018). Hubungan tingkat pengetahuan dengan sikap keluarga tentang perawatan activity daily living (adl) pada lansia. Jombang. Skripsi. STIK Insan Cendekia Medika. Diakses dari

http://repo.stikesicmejbg.a c.id/1312/2/143210125\%20L AILI\%20JAMILATUS\%20SANIFA H\%20\%20skripsi.pdf

Sari, D.P., Atiqoh, N.S. (2020). Hubungan antara pengetahuan masyarakat dengan kepatuhan penggunaan masker sebagai upaya pencegahan penyakit Covid-19 di ngronggah. Jurnal Ilmiah Rekam Medis dan Informatika Kesehatan, Infokes Vol 10 No.1.

Suyanto, Amal, A.I., Noor, M.A., Astutik, I.T. (2018). Analisis data penelitian. Semarang: Jawa Tengah. UNISSULA PRESS. E-book. Diakses dari http://research.unissula.ac.i $\mathrm{d} / \mathrm{bo} /$ reviewer/210909018/8 506lsi_Buku_SPSS.pdf
Wawan, A. \& Dewi, M. (2018). Teori \& Pengukuran Pengetahuan, Sikap, Dan Perilaku Manusia. Yogyakarta, Indonesia: Nuha Medika.

WHO. (2020). Health topics corona virus disease. Jenewa, Swiss: World Health Organization. Diakses dari https://www.who.int/health topics/coronavirus\#tab=tab_ $\underline{2}$

WHO. (2021). Covid-19 explorer. Jenewa, Swiss: World Health Organization. Diakses dari: https://worldhealthorg.shin yapps.io/covid/

WHO. (2021). Situation by country territory \& area. Jenewa, Swiss: World Health Organization. Diakses dari: https://covid19. who.int/tab $\underline{\text { le }}$

Yanti, Nugraha, Wisnawa et al. (2020). Gambaran pengetahuan masyarakat tentang Covid-19 dan perilaku masyarakat di masa pandemi Covid-19. Jurnal Keperawatan Jiwa Volume 8 No.3. Diakses dari:

https: / / jurnal.unimus.ac.id/ index.php/JKJ/article/down load/6173/pdf 